Sädhanā, Vol. 9, Part 3, November 1986, pp. 157-176. (C) Printed in India.

\title{
Improved operating policies for multipurpose use: A case study of Bhadra Reservoir
}

\author{
S VEDULA, S MOHAN and V S SHRESTHA* \\ Department of Civil Engineering, Indian Institute of Science, Banga- \\ lore 560 012, India \\ * Present address: Department of Electricity, Kathmandu, Nepal \\ MS received 31 July 1985; revised 3 January 1986
}

\begin{abstract}
The operation of Bhadra reservoir project is studied using optimization (overyear and within year storage model) and simulation (with both historic and synthetically generated monthly streamflows) based on a 52-year record of monthly inflow data for irrigation and hydropower generation. Bed turbine operation is found to be the key issue in maximizing the total hydropower production. The reservoir operation is studied for thirteen different policies of bed turbine operation using simulation. These simulation runs are carried out for a specified irrigation demand with historic data. The probability distribution of the maximum possible hydropower production is arrived at by simulating the reservoir operation with 4 different sets of synthetically generated monthly streamflows, each having sequences of different lengths, for two promising policies. A comparison of results made with the actual operation over a 11-year period shows that substantial increase in the total hydropower generation is possible with the identified policies without undue deficits in meeting the specified irrigation demands.
\end{abstract}

Keywords. Bhadra Reservoir; operating policies; hydropower generation; optimization and simulation.

\section{Introduction}

Systems analysis has proved time and again to be a potential tool in the planning and management of the available water resources. It is useful in guiding the decision maker in looking at potential configurations and the sizing of the project elements in a new project, and for improving operating policies in the case of existing projects. There are several cases, where systems techniques have been

A list of symbols is given at the end of the paper. 
used to arrive at operating policies for multipurpose reservoirs, in which the derived operating policies have been clearly shown to result in an improvement over the historic performance; see, for example, Thomas \& Revelle (1966), Hall et al (1968), Mobasheri \& Haroboe (1970), Fults \& Hancock (1972), and Beik et al (1984). The present paper is an attempt in the latter direction, applied to a specific reservoir project in the State of Karnataka, being operated for the dual purpose of irrigation and hydropower generation. The Bhadra reservoir project under the present study irrigates the semiarid tracts of Chickamagalur, Shimoga, Chitradurga and Bellary districts besides producing hydropower from both the canal and bed releases. The study, based on 52 years of streamflow data and 11 years of data on actual operation of the reservoir, identifies improved operating policies for better results.

\section{Objectives of present study}

The specific objectives of the present study are: (i) to determine the maximum annual hydropower production at the reservoir while satisfying the specified irrigation demands, using a mathematical programming model. A linear programming model is formulated based on the concept of overyear and within year storages. Historic streamiflow data of two sequences of 25 years each are used in the model; (ii) to examine the tradeoff between irrigation release and hydropower production by simulating the operation of the reservoir using different operating policies based on the historic monthly streamflow data; and (iii) to determine the probability distribution of the maximum possible annual hydropower production based on a simulation of reservoir operation for two potential operating policies identified from the objective (ii) above, using synthetically generated streamflows (divided into different sets, each consisting of sequences of different lengths).

\section{Project description}

The Bhadra Reservoir Project is a multipurpose, river valley project operated for irrigation and hydropower in the State of Karnataka, South India. The Bhadra River originates in the Western ghats and is the main tributary of the Tungabhadra river in the Krishna Basin. The project site is located on the river Bhadra at latitude $13^{\circ} 52^{\prime} \mathrm{N}$ and longitude $75^{\circ} 38^{\prime} \mathrm{E}$ about $1.5 \mathrm{~km}$ upstream from Lakkavalli village in Chickamagalur District, as shown in figure 1 . The drainage area of the river at the dam site is $1968 \mathrm{~km}^{2}$ and is well-forested and fairly rich in rainfall. The capacity of the reservoir is $2025 \mathrm{~m} \mathrm{cu} \mathrm{m} *$ with a dead storage of $241 \mathrm{~m} \mathrm{cu} \mathrm{m}$. Figure 2 shows a schematic diagram of the configuration of the project. There are two canals taking off from the reservoir. The left bank canal is $80 \mathrm{~km}$ long and irrigates $6367 \mathrm{ha}$. The right bank canal with its branches totals $268 \mathrm{~km}$ in length and irrigates 87,512 ha of land. The channel capacities of the left and right bank canals are 10 and 71 cumecs, respectively.

\footnotetext{
${ }^{*} \mathrm{~m} \mathrm{cu} \mathrm{m}=10^{6} \mathrm{~m}^{3}$
} 


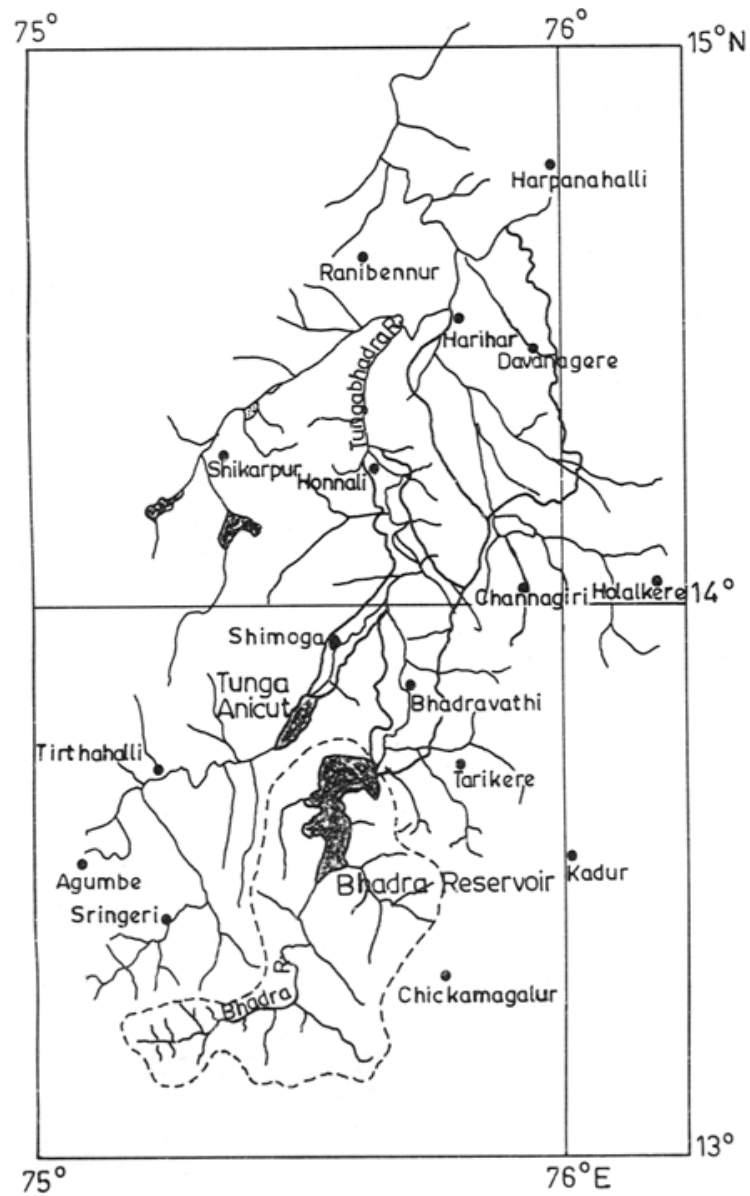

Figure 1. Location map of the Bhadra Reservoir.

There are three sets of turbines that generate hydropower. Two units of $7200 \mathrm{~kW}$ each (a total of $14,400 \mathrm{~kW}$, hereinafter referred to as the right turbine) are run by releases made to the right bank canal. One $2000 \mathrm{~kW}$ unit (hereinafter called the left turbine), is run by releases made to the left bank canal. Two units of $12,000 \mathrm{~kW}$ each (totalling $24,000 \mathrm{~kW}$, hereinafter called the bed turbine) are run by releases made separately from the reservoir discharging into the riverbed downstream. Thus the releases made to the bed turbine have no irrigation value at the project. Water released for irrigation can be used for hydropower by the left and the right turbines, whereas release downstream of the reservoir alone can be used to produce power from the bed turbine. The project is presently in operation.

\section{Data inputs}

There are three important data inputs to the present study: (i) monthly streamflows, (ii) evaporation and (iii) monthly irrigation demands. 


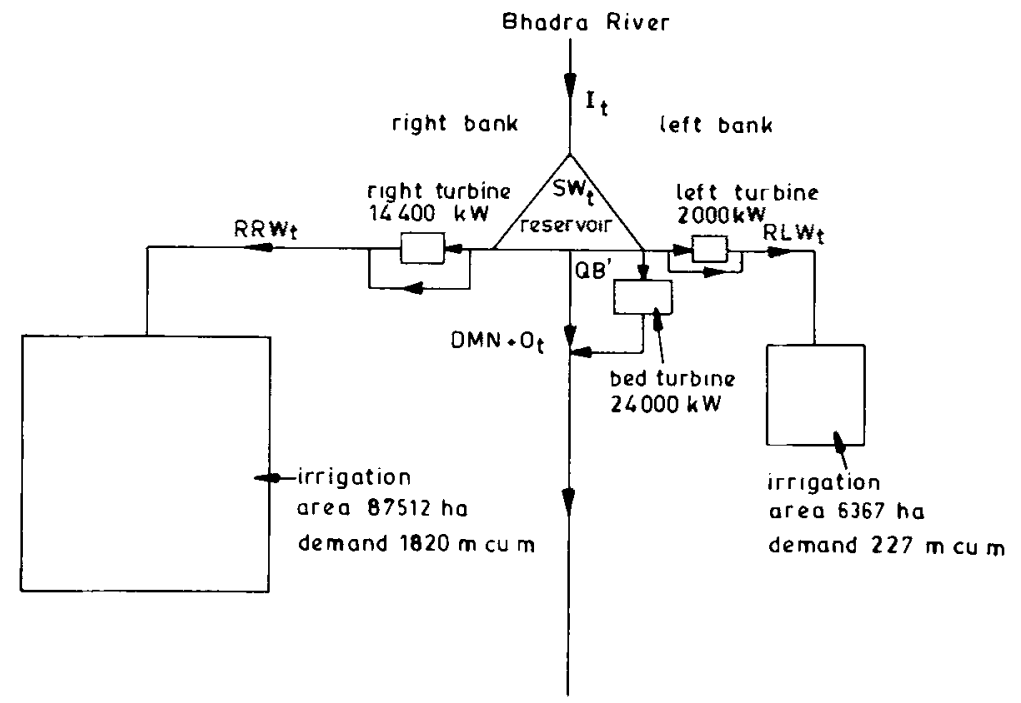

Figure 2. Schematic diagram of the Project.

\subsection{Streamflow}

The average annual inflow (of 52 years) into the reservoir (of $2997.661 \mathrm{~m} \mathrm{cu} \mathrm{m}$ ) is distributed such that $94 \%$ of it occurs during the first six months (June through November) of the water year (June 1 to May 31) and the remainder during the half-yearly period from December to May. Monthly streamflow data at the reservoir site for 52 water years (1930-31 to 1981-82), monthly withdrawal data for 12 calendar years (1971 to 1982), evaporation loss data for 52 calendar years (1930 to 1982), obtained from the Water Resources Development Organisation, Government of Karnataka, are used in the study.

The monthly canal withdrawal data consist of irrigation releases into the left and right bank canals for 12 years (1971 to 1982). In addition, a downstream release of $8.565 \mathrm{~m} \mathrm{cu} \mathrm{m}$ has been shown to have been released on a constant basis almost all the months.

\subsection{Evaporation loss}

Based on the beginning and end-of-the-month reservoir elevations and the evaporation loss data from 1930-31 to 1974-75, the relationship (Shreshta 1976) between the monthly evaporation loss, $L_{t}$, and the average storage volume, $\left(S W_{t}+S W_{t+1}\right) / 2$, was determined as

$$
L_{t}=7.388+0.003\left(S W_{t}+S W_{t+1}\right) \text {. }
$$

Equation 1 is used along with the within year storage continuity constraints; whereas for the overyear constraints, a constant value of $124.76 \mathrm{~m} \mathrm{cu} \mathrm{m}$, being the average annual evaporation loss based on pan evaporation measurements in the last eight years (1974 and 1976-1982) is used for each of the years in the model.

\subsection{Irrigation demand}

Table 1 gives the distribution of the 93,879 ha of irrigated area into its four major crops - paddy, sugarcane, permanent garden and semidry kharif crops - under the 
Table 1. Cropwise distribution (ha)

\begin{tabular}{lccccc}
\hline & $\begin{array}{c}\text { Paddy } \\
(\text { kharif }) \\
(35 \%)\end{array}$ & $\begin{array}{c}\text { Sugarcane } \\
(25 \%)\end{array}$ & $\begin{array}{c}\text { Permanent } \\
\text { garden } \\
(19 \%)\end{array}$ & $\begin{array}{c}\text { Semidry } \\
\text { (kharif) } \\
\text { crops } \\
(21 \%)\end{array}$ & $\begin{array}{c}\text { Total } \\
(100 \%)\end{array}$ \\
\hline Left bank & 3484 & 1713 & 303 & 867 & 6367 \\
Right bank & 29374 & 21757 & 17534 & 18847 & 87512 \\
Total & 32858 & 23470 & 17837 & 19714 & 93879 \\
\hline
\end{tabular}

left and right bank canal commands of the project. The duration of the crops and their starting dates for the purpose of computing the crop water requirements are shown in table 2 . The crop water requirements are computed based on the guidelines given by the Water Management Division (1971).

For purposes of estimating crop water requirements, monthly evaporation data at Hiriyur, Chitradurga District, collected from the Water Resources Development Organisation, Government of Karnataka, were used. The crop factors used for paddy, sugarcane, permanent garden and semidry kharif crops correspond to rice (Los Banos), sugarcane (Hawaii), Group E crops (pastures, orchards and cover crops), and maize (Alabama), respectively, in the publication of the Water Management Division (1971). On-farm losses of $30 \%$ and conveyance losses of $20 \%$ were used in arriving at the canal head requirements from the net irrigation requirements in the field. The computed monthly canal release requirements were then compared with the average monthly withdrawals from the field data and the greater of these two values is taken as the irrigation demand for each month in the present study. The average monthly withdrawals are based on actual withdrawals for the twelve calendar years (1971-82) guided by the requirements based on the duty concept. Table 3 lists the monthly computed canal releases, average actual canal withdrawals and the irrigation demands as used in the present study.

\section{Model for overyear operation}

In the present problem, the reservoir capacity is fixed and the monthly irrigation demands are specified. The objective of the model is to find the withdrawal pattern from the reservoir, for a given set of inflows, such that the annual hydropower generation is a maximum while also meeting the irrigation needs. To this end, a linear programming model based on the concepts of overyear storage and within

Table 2. Crops and their duration

\begin{tabular}{lcc}
\hline Crop & $\begin{array}{c}\text { Duration } \\
\text { (days) }\end{array}$ & Sowing date \\
\hline Paddy & 145 & June 15 \\
Sugarcane & 365 & July 1 \\
Permanent garden & 365 & June 1 \\
Semidry crops & 123 & July 1 \\
\hline
\end{tabular}


Table 3. Irrigation demands at the canal head ( $\mathrm{m} \mathrm{cu} \mathrm{m}$ )

\begin{tabular}{|c|c|c|c|c|c|c|c|}
\hline \multirow[b]{2}{*}{ Month } & \multicolumn{3}{|c|}{ Left Bank } & \multicolumn{3}{|c|}{ Right Bank } & \multirow[b]{2}{*}{$\underset{\text { Temand }}{\text { Tetal }}$} \\
\hline & $\begin{array}{l}\text { Computed } \\
\text { canal } \\
\text { releases }\end{array}$ & $\begin{array}{c}\text { Canal } \\
\text { with- } \\
\text { drawals }^{2}\end{array}$ & $\begin{array}{c}\text { Demand used } \\
\text { in present } \\
\text { study }^{3} \\
\left(I L W_{t}\right)\end{array}$ & $\begin{array}{l}\text { Computed } \\
\text { canal } \\
\text { releases }^{1}\end{array}$ & $\begin{array}{c}\text { Canal } \\
\text { with- } \\
\text { drawals }\end{array}$ & $\begin{array}{c}\text { Demand used } \\
\text { in present } \\
\text { study }^{3} \\
\left(I R W_{t}\right)\end{array}$ & \\
\hline June & $8 \cdot 9$ & $5 \cdot 3$ & 8.9 & $111 \cdot 0$ & $44 \cdot 1$ & 111.0 & 119.9 \\
\hline July & $6 \cdot 2$ & $15 \cdot 0$ & $15 \cdot 0$ & $76 \cdot 9$ & $121 \cdot 8$ & $121 \cdot 8$ & $136 \cdot 8$ \\
\hline August & 9.7 & $21 \cdot 1$ & $21 \cdot 1$ & $117 \cdot 2$ & $179 \cdot 5$ & $179 \cdot 5$ & $200 \cdot 6$ \\
\hline September & $9 \cdot 6$ & $22 \cdot 3$ & $22 \cdot 3$ & $117 \cdot 5$ & $173 \cdot 5$ & $173 \cdot 5$ & $195 \cdot 8$ \\
\hline October & $6 \cdot 6$ & $24 \cdot 3$ & $24 \cdot 3$ & $94 \cdot 2$ & $178 \cdot 9$ & 178.9 & $203 \cdot 2$ \\
\hline Novenıber & $4 \cdot 0$ & $21 \cdot 2$ & $21 \cdot 2$ & $78 \cdot 3$ & $168 \cdot 5$ & $168 \cdot 5$ & $189 \cdot 7$ \\
\hline December & $5 \cdot 2$ & $8 \cdot 0$ & $8 \cdot 0$ & $101 \cdot 4$ & $54 \cdot 3$ & $101 \cdot 4$ & 109.4 \\
\hline January & $6 \cdot 1$ & $16 \cdot 5$ & $16 \cdot 5$ & $116 \cdot 1$ & $120 \cdot 8$ & $120 \cdot 8$ & $137 \cdot 3$ \\
\hline February & $7 \cdot 0$ & $21 \cdot 2$ & $21 \cdot 2$ & $142 \cdot 8$ & $158 \cdot 9$ & 158.9 & $180 \cdot 1$ \\
\hline March & $9 \cdot 6$ & $22 \cdot 7$ & $22 \cdot 7$ & $174 \cdot 6$ & $172 \cdot 8$ & $174 \cdot 6$ & $197 \cdot 3$ \\
\hline April & 9.6 & $24 \cdot 0$ & $24 \cdot 0$ & 159.7 & 173.9 & 173.9 & 197.9 \\
\hline May & $7 \cdot 3$ & $21 \cdot 3$ & $21 \cdot 3$ & $116 \cdot 6$ & $157 \cdot 3$ & $157 \cdot 3$ & 178.6 \\
\hline $\begin{array}{l}\text { Annual } \\
\text { total }\end{array}$ & $89 \cdot 8$ & $222 \cdot 9$ & $226 \cdot 5$ & $1406 \cdot 3$ & $1704 \cdot 3$ & $1820 \cdot 1$ & $2046 \cdot 6$ \\
\hline
\end{tabular}

\footnotetext{
1 as per crop water requirements;

2 actuals averaged over 12 calendar years, 1971-82;

${ }^{3}$ greater of the values in ${ }^{1}$ and ${ }^{2}$ above.
}

year storage (Loucks et al 1981) is formulated for the Bhadra Reservoir for a period of 25 years (Mohan 1983). Overyear storage is required to take care of the variations in the yearly inflows in meeting the irrigation demands. The average annual inflow (based on 52 years of data) is $2997.7 \mathrm{~m} \mathrm{cu} \mathrm{m}$, while the annual irrigation demand is $2046.5 \mathrm{~m}$ cu $\mathrm{m}$. However, overyear storage is needed because every year's inflow will not be equal to the average inflow, or for that matter, the irrigation demand. Within the year storage is required because of the mismatch between the distribution of the annual inflow among the different months and the distribution of the canal irrigation demand among the months. Conceptually, the monthly within year storage requirements can be computed for a given demand distribution in an average year (with average annual inflow). The largest of these monthly storages defines the within year storage capacity. The overyear storages are computed for a given annual demand taking into account the inflows in each year of the period of analysis.

The objective is to maximize the total annual hydropower production (energy in million kilowatt hours) from the left $(E L)$, right $(E R)$ and the bed turbines $(E B)$ together.

Objective: Maximize $(E L+E R+E B)$.

\subsection{Constraints}

5.1a Overyear storage continuity constraints: The continuity of storage from year to year requires that, for any year, the initial storage plus inflow minus the withdrawals for irrigation into the left and right banks, withdrawal for the bed turbine, downstream release and spill (if any), and evaporation equals the initial 
storage for the next year, thus:

$$
\begin{aligned}
S_{y}+I_{y}- & \left(\alpha_{y} Y+10.756 E B+L+D Y R+O_{y}\right) \\
= & S_{y+1}, y=1,2, \ldots 25,
\end{aligned}
$$

with $S_{y+1}=S_{1}$ for $y=25$. In the constraint (3), $Y$ is equal to the total annual irrigation demand of $2046.6 \mathrm{~m} \mathrm{cu} \mathrm{m}$ and $\alpha_{y}$ is the ratio of the annual irrigation demand to be met in the year $y$. As the capacity of the reservoir is fixed, a very low inflow in a year may not permit the full demand to be met thus necessitating the introduction of $\alpha_{y}$. The constant 10.756 is a factor which when multiplied converts the energy in $10^{6} \mathrm{kWh}$ produced by the bed turbine into the quantity of flow required in $\mathrm{m} \mathrm{cu} \mathrm{m}$ when the reservoir water level is at an elevation of $47 \cdot 7^{\dagger} \mathrm{m}$. For hydropower computations, a constant head is assumed for each turbine corresponding to this reservoir elevation. The corresponding head available is $40.994 \mathrm{~m}$ for the bed turbine, $34.898 \mathrm{~m}$ for the left turbine and $14.964 \mathrm{~m}$ for the right turbine. For purposes of energy computations, it is assumed that the load factor is 0.62 , the loss of head in the penstocks is $2 \%$ and the efficiency of hydropower generation is $85 \%$. The annual evaporation loss, $L$, and the annual downstream release through the river sluices (exclusive of the bed turbine release), DYR, are assumed constant at 124.76 and $102.78 \mathrm{~m}$ cu $\mathrm{m}$ respectively.

The overyear storage capacity, $K_{0}$, is defined by the constraint,

$$
S_{y} \leq K_{0}, \text { for all } y^{*}
$$

5.1b Within year storage constraints: Within year storage constraints relate the continuity of storage from month to month in a year of average inflows. The constraint specifies that the initial storage plus the inflow minus the withdrawals (for irrigation in the left and right banks and for the bed turbine power generation) and evaporation in a month, $t$, should equal the initial storage for the next month $(t=1$ refers to June). This condition coupled with (1) gives

$$
\begin{gathered}
1.003 S W_{t+1}-0.997 S W_{t}+R L W_{t}+R R W_{t}+10.756 E B W_{t}+O_{t} \\
=I_{t}-7.388-D M R, t=1,2, \ldots 12,
\end{gathered}
$$

with $S W_{t+1}=S W_{1}$ for $t=12$. The term $I_{t}$ denotes average monthly inflow for month $t$ and $D M R$ the constant monthly downstream release in $\mathrm{m} \mathrm{cu} \mathrm{m}$. Within year storage capacity is defined as

$$
S W_{t} \leq K_{w}, t=1,2, \ldots 12 .
$$

5.1c Irrigation release constraints: The monthly irrigation releases should be at least equal to the irrigation demands.

$$
\begin{aligned}
& R L W_{t} \geq I L W_{t}, \quad t=1,2, \ldots 12, \\
& R R W_{t} \geq I R W_{t}, \quad t=1,2, \ldots 12 .
\end{aligned}
$$

(It is to be noted that $Y=\sum_{t=1}^{12}\left(I L W_{t}+I R W_{t}\right)$ )

\footnotetext{
Above river bed.

* Hereafter, 'for all' will be denoted by the symbol $\forall$, e.g., in (4) $S_{y} \leq K_{0}, \forall y$.
} 
The quantities $I L W_{t}$ and $I R W_{t}$ are listed in table 3 for all the months.

Also, the irrigation releases cannot be greater than the respective channel capacities (Shreshta 1976), thus:

$$
\begin{aligned}
& R L W_{t} \leq 26.068 \forall t, \\
& R R W_{t} \leq 186.201 \forall t .
\end{aligned}
$$

5.1d Hydropower constraints: As mentioned earlier, a constant head is assumed for each turbine corresponding to a reservoir water level elevation of $47.7 \mathrm{~m}$ in the reservoir. In order that the water passing through the turbines be limited to the canal withdrawals, the following constraints hold.

$$
\begin{aligned}
& R L W_{t} \geq 12.634 E L W_{t}, \forall t, \\
& R R W_{t} \geq 29.465 E R W_{t}, \forall t,
\end{aligned}
$$

where 12.634 and 29.465 are conversion factors to convert energy in $10^{6} \mathrm{kWh}$ produced by the left and the right turbines, respectively, to volume of flow in $\mathrm{m}$ cu $\mathrm{m}$. The capacity production constraints are

$$
\begin{aligned}
& E L W_{t} \leq 0.906 \forall t, \\
& E B W_{t} \leq 10.872 \forall t .
\end{aligned}
$$

The other constraint that $E R W_{t} \leq 6.523$ becomes redundant in the light of the constraints 10 and 12 . Also constraint 11 is redundant because of the constraints 9 and 13 .

5.1e Storage capacity constraints: The storage in any month $t$ should be more than the dead storage.

$$
S W_{t} \geq 240 \cdot 695 \text {. }
$$

The sum of the overyear and within year storage capacities should not exceed the total reservoir capacity,

$$
K_{0}+K_{w} \leq 2024 \cdot 666
$$

5.1f Link constraints: The following constraints link the within year hydropower production to the yearly generation for the left, right and the bed turbine, respectively:

$$
\begin{aligned}
& E L \leq \sum_{t=1}^{12} E L W_{t}, \\
& E R \leq \sum_{t=1}^{12} E R W_{t}, \\
& E B \leq \sum_{t=1}^{12} E B W_{t} .
\end{aligned}
$$


The constant level of $47.7 \mathrm{~m}$ assumed for power computation is verified to be consistent with the overyear and within year storage values obtained in the solution of the optimization runs within half a metre.

\subsection{Solution}

The model has been applied to two sequences of historic streamflows each of 25 years length: the first sequence running from the water year 1932-33 to the water year 1956-57 and the second from 1957-58 to 1981-82. There are 140 variables and 188 constraints for the linear programming (LP) model in each case. The model operation for these two sequences reveals the extent of possible power generation within the constraints of the irrigation demands imposed.

5.2a Sequence 1 (1932-33 to 1956-57): The ratio of the least yearly inflow to the average annual flow during the 25 year period of sequence 1 is $0 \cdot 68$. The results of the run for $\alpha_{y}$ set equal to 1.0 for all the years are shown in table 4 . The irrigation demands are satisfied to the full extent in all the years in this case. The maximum total annual hydropower generation on a constant basis is $106.986 \times 10^{6} \mathrm{kWh}$. The left turbine operates at capacity for all months at $0.906 \times 10^{6} \mathrm{kWh}$ except in July when the production is $0.633 \times 10^{6} \mathrm{kWh}$.

The right turbine, however, can use more water than is needed to be released to satisfy the irrigation demands. As the operating head for the bed turbine is higher than for the right turbine, the solution gives the canal withdrawals just equal to the irrigation demands and additional water is released through the bed turbine in preference to the right turbine for higher power production. The right turbine, as a consequence, does not reach its capacity any time.

5.2b Sequence 2 (1957-58 to1981-82): The value of $\alpha_{y}$ for each of the three lowest inflow years is made equal to the ratio of that year's inflow to the annual average. For the rest of the 22 years $\alpha_{y}$ is set equal to 1 . Thus $\alpha_{9}=0.45$ applies for the year 1965-66, $\alpha_{10}=0.43$ for 1966-67 and $\alpha_{20}=0.54$ for 1976-77. This implies that in those years the annual irrigation demand is satisfied only partially because of poor inflows. The monthly demands, therefore, are to be implicitly satisfied to the extent of $100 \alpha_{y} \%$ for the corresponding year $y$. The results of the optimization model are shown in table 4 . The maximum annual power generation is $105.543 \times 10^{6} \mathrm{kWh}$ with a reduction of less than $1.5 \%$ of the value possible with

Table 4. Results of storage model (irrigation demands fully satisfied)

\begin{tabular}{|c|c|c|c|c|c|c|c|}
\hline & $\begin{array}{c}K_{0} \\
(\mathrm{~m} \mathrm{cu} \mathrm{m})\end{array}$ & $\left(\begin{array}{c}K_{n} \\
\mathrm{cu} \mathrm{m})\end{array}\right.$ & $\begin{array}{c}\text { Total } \\
\text { capacity } \\
(\mathrm{m} \text { cu } \mathrm{m})\end{array}$ & $\begin{array}{c}E L \\
\left(10^{6} \mathrm{kWh}\right)\end{array}$ & $\begin{array}{c}E R \\
\left(10^{6} \mathrm{kWh}\right)\end{array}$ & $\begin{array}{c}E B \\
\left(10^{6} \mathrm{kWh}\right)\end{array}$ & $\begin{array}{c}\text { Total } \\
\text { energy } \\
\left(10^{6} \mathrm{kWh}\right)\end{array}$ \\
\hline $\begin{array}{l}\text { Sequence } 1 \\
\alpha_{v}=1.0 \forall y\end{array}$ & $960 \cdot 593$ & $1064 \cdot 073$ & $2024-666$ & $10 \cdot 599$ & $61 \cdot 768$ & $34 \cdot 619$ & $106 \cdot 986$ \\
\hline $\begin{array}{l}\text { Sequence 2 } \\
\alpha_{9 y}(1965-66)=0.45 \\
\alpha_{10}(1966-67)=0.43 \\
\alpha_{20}(1976-77)=0.54\end{array}$ & $1376 \cdot 773$ & $647-893$ & $2024-666$ & $10 \cdot 398$ & $61 \cdot 768$ & $33 \cdot 377$ & $105 \cdot 543$ \\
\hline
\end{tabular}


sequence 1. If full irrigation demands for all years are insisted upon with sequence 2 , the solution, naturally, would have been infeasible.

\section{Simulation}

The simulation study was carried out in two stages. First, the reservoir operation is simulated on a monthly basis for the historic data of 52 years for 13 different operating policies each of which defines the way the bed turbine should be operated to increase power production. The part of the policy for regulating the irrigation canal releases is, however, the same for all the policies. A comparison is made with the existing operation for the few years for which field data are available. Secondly, two of the most promising of these operating policies were used to simulate the reservoir operation over different lengths of synthetically generated monthly streamflow sequences to determine the frequency distribution of the annual hydropower that can be generated from the reservoir project.

\subsection{Operating policies}

6.1a Irrigation releases: In a normal year, the inflows are sufficient to meet irrigation demands. Shortages are imminent in low inflow years. Though the irrigation shortage cannot be eliminated in each year, the irrigation release policy is aimed at eliminating the shortage for the more important kharif season (than rabi). Thus the irrigation release policy boils down to the specification of the release pattern in the rabi season.

A set of beginning of month storages are computed following Shreshta (1976) for the months from December to May such that the computed or higher value for any month when maintained in the reservoir (at the beginning of the month) ensures full supply of irrigation demand for that and the following months in that water year. This, however, may require the shutting-off of the bed turbine during some months. These storages are computed backward starting from May. For this purpose, it is assumed that the reservoir would have only dead storage on June 1 and the beginning of the storage for May equals the sum of the irrigation demand, constant downstream release and evaporation loss for May. The storages for the months of April, March, February, January and December are computed in a similar way. The inflows during these months are not taken into account, as they are small compared to the storages required and to this extent, as will be seen subsequently, the release policy will be conservative. The beginning of month storages thus computed are tabulated in table 5. If the storage at the beginning of any month falls short of the computed value, irrigation shortage is very likely to occur in the subsequent period (in the rabi season). The irrigation releases in the rabi season are thus regulated as follows.

If in a simulation run, the actual reservoir storage at the beginning of a month is greater than or equal to the computed value, then the full irrigation demand is released and the bed turbine allowed to operate as per the policy described in $\$ 6.1 \mathrm{~b}$ below. On the other hand, if the actual storage at the beginning of the month falls below the computed value, the irrigation release is reduced in the ratio of the available live storage to the live storage corresponding to the computed (beginning 
Table 5. Beginning of month storages

\begin{tabular}{lc}
\hline Month & $\begin{array}{c}\text { Beginning of month } \\
\text { storages (m cu m) }\end{array}$ \\
\hline May & $437 \cdot 045$ \\
April & $653 \cdot 449$ \\
March & $870 \cdot 282$ \\
February & $1071 \cdot 120$ \\
January & $1230 \cdot 387$ \\
December & $1362 \cdot 948$ \\
\hline
\end{tabular}

of the month) storage for that month, and the bed turbine is shut down for that month. This principle is applied for all the months in the rabi season beginning from December.

6.1b Power generation policy: There is difficulty in operating the bed turbine at its full capacity just when the reservoir water level rises above the minimum stipulated for the turbine operation. The level in the next month may drop down to such an extent that the bed turbine may have to be shut off. Such difficulties are not posed by the left and right turbines as water is released through the canals for irrigation anyway and whatever power can be generated with these releases will be generated. This calls for a strategic policy for bed turbine operation.

Any release made through the bed turbine in a month reduces storage in the reservoir that might lead to an irrigation shortage in the next month. Keeping these considerations in view, a reservoir level $H B$ is to be chosen at and above which the bed turbine is operated at full (or at a specified percentage of its) capacity and below which it is operated only at part capacity as per the operating policy in (20) below. The release through the bed turbine, $Q B^{\prime}$ is then specified as follows:

$$
Q B^{\prime}=Q B\left(H-H_{0}\right) /\left(H B-H_{0}\right), \text { for } H \leq H B .
$$

Thus the bed turbine is brought from zero capacity operation to full capacity operation in a linear manner as the reservoir level rises from the minimum (permissible for power generation) to the specified or chosen value $H B$. The required water is released to the turbine to satisfy this condition. The lower the value of $H B$, the higher the power generation from the bed turbine and the greater is the risk of irrigation shortage in the subsequent months.

\subsection{Historic streamflow sequence}

6.2a Simulation with different operating policies: Simulation runs are made for a 52-year historic streamflow sequence (1930-31 to 1981-82) for thirteen different operating policies (Mohan 1983) starting from the dead storage level for the first month of the first year. The runs in the present study are made with a revised irrigation demand pattern compared to that used in Mohan (1983). The details of the computer programme with its various subroutines are given in Shreshta (1976). Table 6 gives the specification of the thirteen policies used in the simulation runs numbered 1 to 13 . These thirteen runs give a range of annual irrigation releases 
Table 6. Operating policies for simulation

\begin{tabular}{lcc}
\hline $\begin{array}{l}\text { Run } \\
\text { number }\end{array}$ & $\begin{array}{c}\text { Bed turbine } \\
\text { capacity } \\
(\%)\end{array}$ & $\begin{array}{c}\text { Specified reservoir } \\
\text { level, } H B \\
(\mathrm{~m})\end{array}$ \\
\hline 1 & 0 & - \\
2 & 25 & $56 \cdot 693^{*}$ \\
3 & 50 & $56 \cdot 693$ \\
4 & 75 & $56 \cdot 693$ \\
$5^{\ddagger}$ & 100 & $56 \cdot 693$ \\
6 & 100 & $54 \cdot 406^{\dagger}$ \\
7 & 100 & $52 \cdot 000$ \\
8 & 100 & $50 \cdot 000$ \\
9 & 100 & $48 \cdot 000$ \\
10 & 100 & $46 \cdot 000$ \\
11 & 100 & $44 \cdot 000$ \\
12 & 100 & $42 \cdot 000$ \\
13 & 100 & $40 \cdot 000$ \\
\hline
\end{tabular}

* Maximum reservoir level (above the river bed)

${ }^{\dagger}$ Maximum reservoir level for operation of Right Turbine

\# In this run, for example, the bed turbine is brought to the $100 \%$ capacity at a reservoir elevation of $56.693 \mathrm{~m}$.

with the corresponding amounts of energy production so that average annual values resulting from the various policies may be compared. Figure 3 gives the trade-off curve between the total irrigation water supplied and the corresponding total energy that can be generated, both expressed in terms of average values over the 52-year period for each policy. The scale of irrigation shortages (from the demands used in this study) is also marked in percent on the $x$-axis of figure 3 .

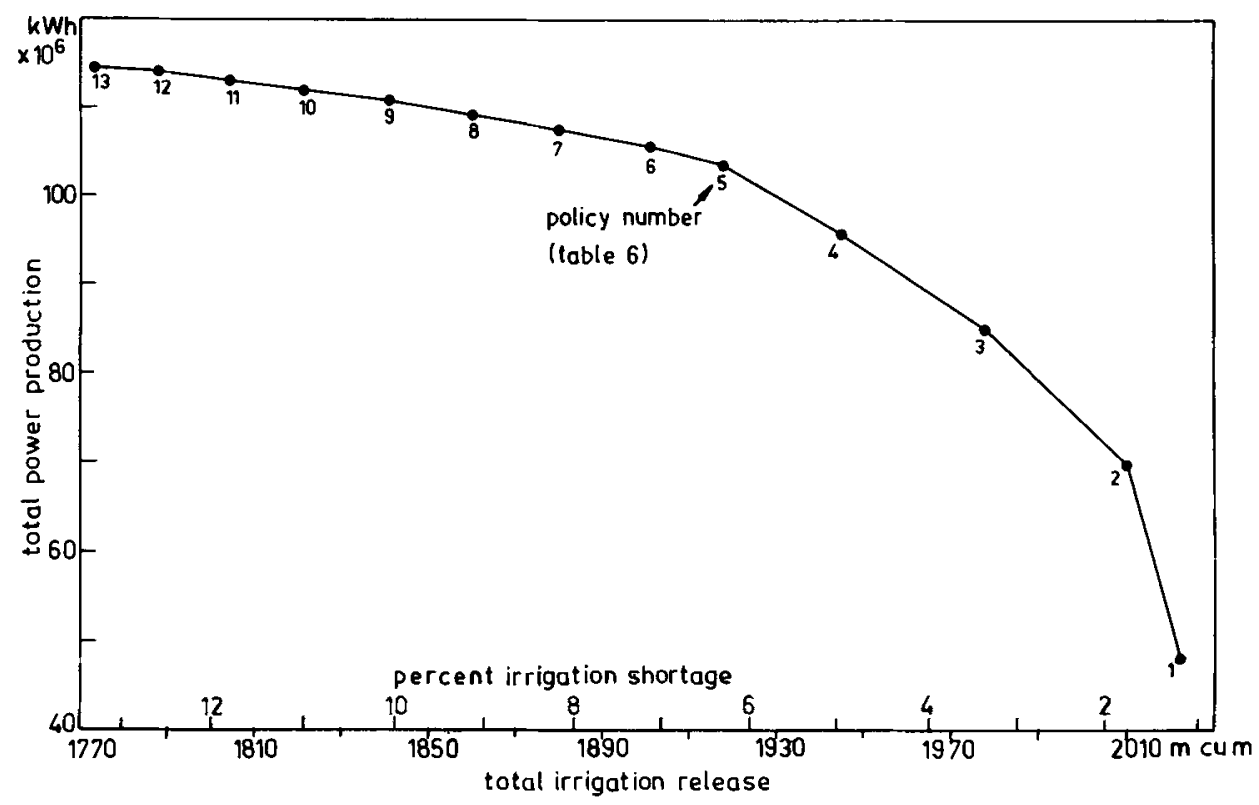

Figure 3. Trade-off between irrigation release and hydropower. 


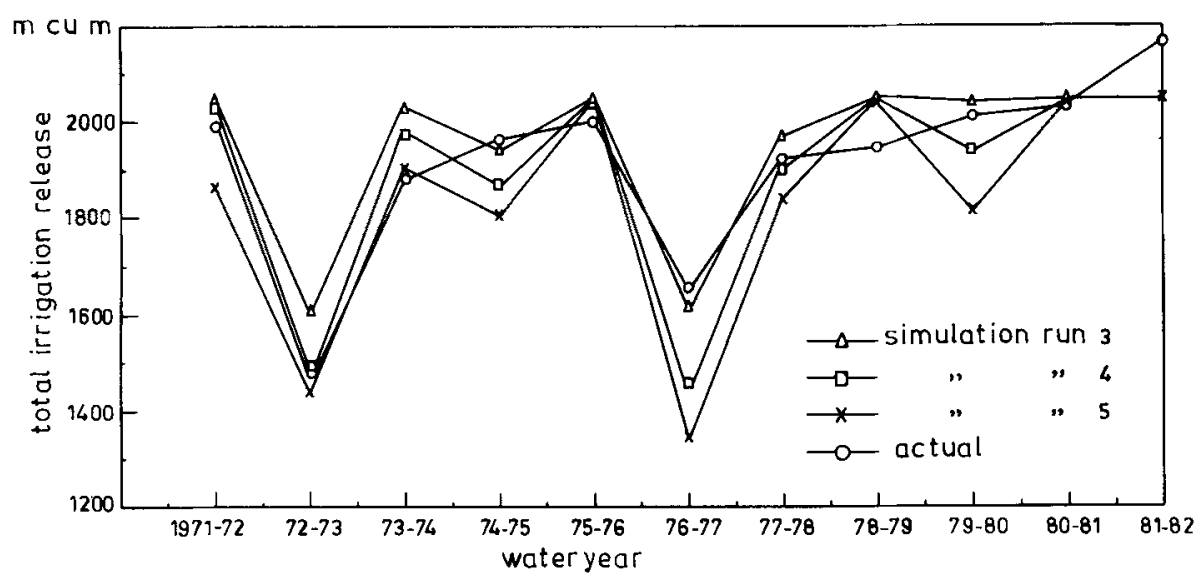

Figure 4. Comparison between simulated and actual irrigation releases.

6.2b Comparison with existing operation: Figures 4, 5 and 6 give the results of the simulation runs for the 11 years, $1971-72$ to $1981-82$, for which field data are available for comparison. The data on the actual hydropower generated monthwise during these years were obtained from the Divisional Office of the Karnataka Power Corporation at the project site. The results of only the most promising

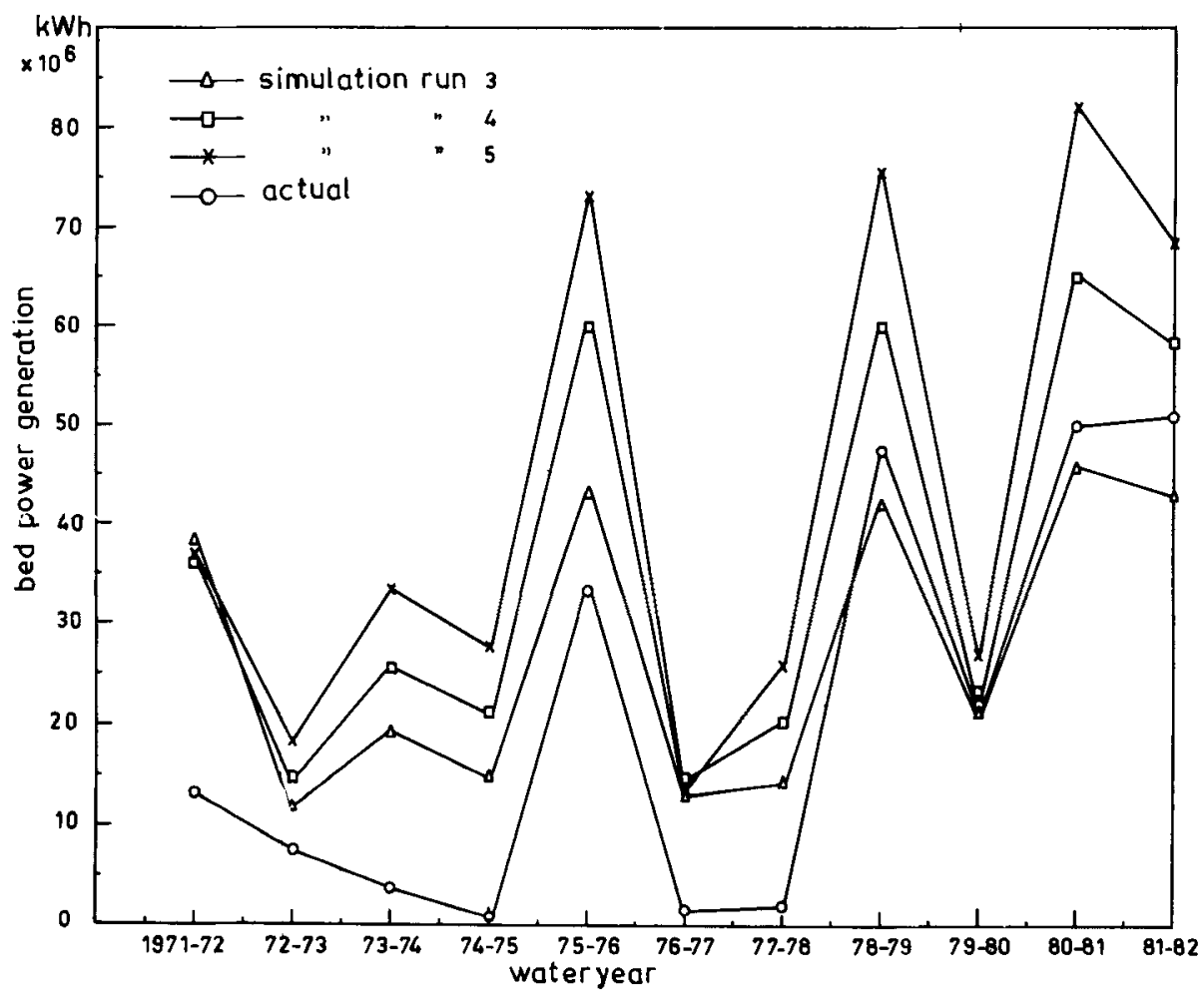

Figure 5. Comparison between simulated and actual bed power generation. 


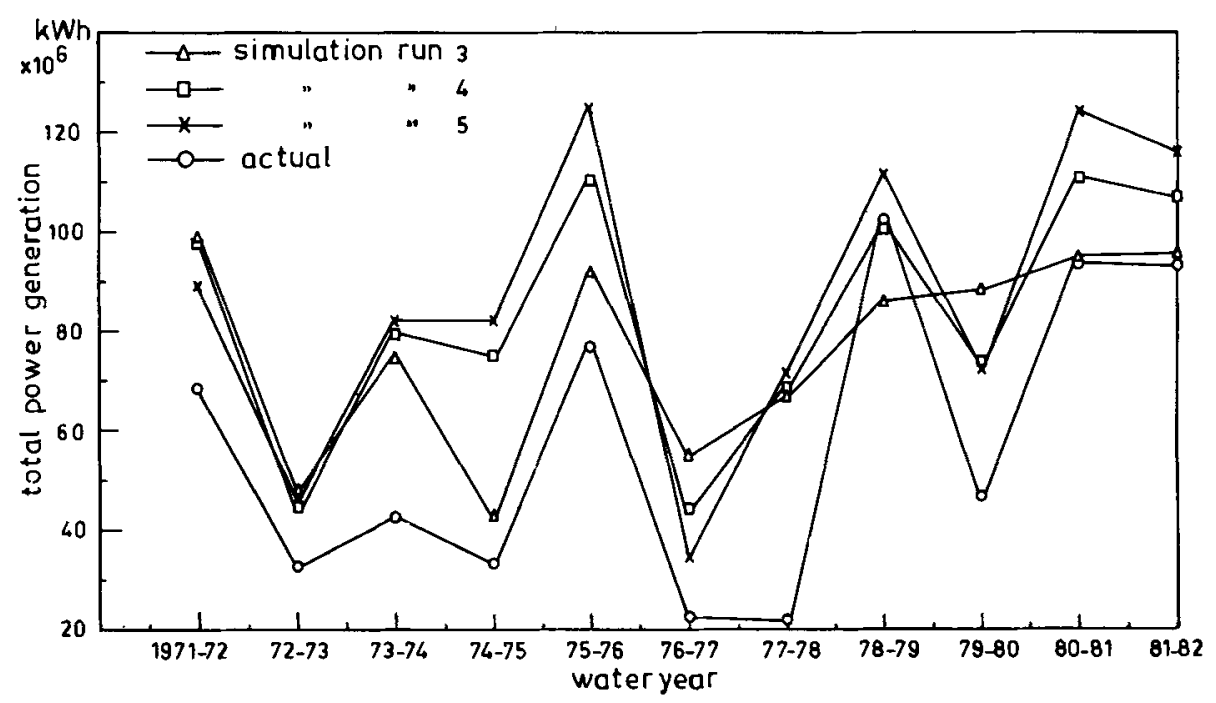

Figure 6. Comparison between simulated and actual total power generation.

simulation runs 3,4 and 5 are shown in the figure for comparison. It is found from the simulation runs for the 13 different policies that all the runs except 3,4 and 5 resulted in more than $5 \%$ deficit in the average annual irrigation release (average for the 11 years considered above) compared with the average of the amounts actually released in those years. On this basis, the results of the three promising simulation runs 3,4 and 5 are analysed in detail. The annual values of the total irrigation release are plotted in figure 4 for each of the three policies. It is seen from the figure that the irrigation release decreases, in general, from policy 3 to policy 4 and then further with policy 5 in that order, as may be expected. The exception is in the case of 3 years, 1975-76, 1978-79 and 1980-81 in all of which the yearly inflow is quite high compared with the annual average, with the result that what has been demanded has been released to the full extent.

Table 7 gives the comparison of the average values of the irrigation release and the hydropower generated with actual achievements over the 11 years. From the

Table 7. Summary of results of comparison with existing operation (Period 11 years: 1971-72 to 1981-82)

\begin{tabular}{lcccc}
\hline & \multicolumn{4}{c}{ Average annual values } \\
\cline { 2 - 5 } Quantity & Actuals & Policy 3 & Policy 4 & Policy 5 \\
\hline $\begin{array}{l}\text { Inflow* (m cu m) } \\
\begin{array}{l}\text { Irrigation } \\
\text { release (m cu m) }\end{array}\end{array}$ & 2701 & - & - & - \\
$\begin{array}{l}\text { Bed turbine } \\
\text { power production, } \\
\left(10^{6} \mathrm{kWh}\right)\end{array}$ & 21.2 & 27.9 & 36.4 & 43.9 \\
$\begin{array}{l}\text { Total power } \\
\text { production } \\
\left(10^{6} \mathrm{kWh}\right)\end{array}$ & 57.1 & 77.8 & 82.5 & 85.8 \\
\hline
\end{tabular}

* 52 years average $=2998 \mathrm{~m}$ cu $\mathrm{m}$. 
average values computed for the eleven years, it is seen from table 7 that the release is $1.9 \%$ in excess for policy $3,0.9 \%$ in deficit for policy 4 and $4 \%$ in deficit for policy 5 compared with the (11-year) actual average value.

The performance of the bed turbine power generation can be seen from figure 5 . Policies 4 and 5 produce higher power than the actual achievement in all the 11 years, whereas policy 3 produces such a result in 7 out of 11 years. On an average over the 11 years, the average annual bed turbine power generation is higher by $32 \%$ with policy $3,72 \%$ with policy 4 and $107 \%$ with policy 5 , as can be seen from table 7 .

In terms of the total hydropower generation from all the three turbines, it is seen from figure 6 that policies 3,4 and 5 gave better results than actual achievements for all the years except one. The crisscrossing of the lines for the policies 3, 4 and 5 prior to the years $1972-73,1976-77$ and $1979-80$ is because these years represent the three lowest inflow years in the 11 years tested. However, table 7 shows that, on the average, policies 3,4 and 5 generate $36 \%, 45 \%$ and $50 \%$ higher total hydropower than the average annual value actually realised for the 11-year period.

This is a significant result considering the frequent acute power shortage the State of Karnataka experiences from time to time. The price that is paid for this excess energy production is the shortage of $0.9 \%$ or $4 \%$ average annual irrigation release depending on policy 4 or policy 5 that is used compared with the average annual actual release for the 11-year period. Thus policies 4 and 5 demonstrate substantial increase in the annual hydropower generation at Bhadra reservoir without undue sacrifices in irrigation supplies. Analysis based on a long term simulation based on historic or generated sequences of streamflow data shows even better results as will be discussed subsequently from the results shown in table 8 .

\subsection{Synthetic streamflow sequences}

6.3a Generation of synthetic streamflows: From the available historic data (of monthly streamflows) for 52 years, monthly streamflows are synthetically generated using the Thomas-Fiering model (Fiering \& Jackson 1971) for 1050 years. The first 50 years of generated flows are discarded (for bias likely to be associated with the choice of the initial value used for generation) and the data for the remaining 1000 years are divided into sequences of different lengths for simulation.

6.3b Simulation with generated streamflows: The 1000 years of generated monthly streamflows are divided into. 4 sets of sequences of different lengths - (i) 50 sequences of 20 years each, (ii) 40 sequences of 25 years each, (iii) 25 sequences of 40 years each, and (iv) 20 sequences of 50 years each. Two operating policies are selected for simulation with these four sets. These policies correspond to runs 4 and 5 in table 6. For each of these policies, as many simulation runs are made as the number of sequences in each of the four sets of generated data. For a given set, the average annual power production is computed for each sequence thus enabling the computation of the exceedance probabilities for that set. These probabilities are obtained for each set with each of the two policies used. The probability distribution of the average annual power production obtained thus is plotted in figure 7 for policy 4 and in figure 8 for policy 5 . These plots show that beyond an exceedance probability of $0 \cdot 2$, the total hydropower generated is not sensitive to 
Table 8. Summary of results of optimization and simulation

\begin{tabular}{|c|c|c|c|}
\hline \multirow[b]{2}{*}{ Model } & \multicolumn{3}{|c|}{ Average annual value } \\
\hline & $\begin{array}{l}\text { Irrigation demand } \\
\text { satisfied }(\%)\end{array}$ & $\begin{array}{l}\text { Energy prodi } \\
\text { Historic data }\end{array}$ & $\begin{array}{l}\text { tion }\left(10^{6} \mathrm{kWh}\right) \\
\text { Generated data }\end{array}$ \\
\hline $\begin{array}{l}\text { Optimization model } \\
\text { (a) Sequence I }(25 \mathrm{yrs}) \\
\text { (b) Sequence II }(25 \mathrm{yrs})\end{array}$ & $\begin{array}{l}100 \\
100^{*}\end{array}$ & $\begin{array}{l}106 \cdot 99 \\
105 \cdot 54\end{array}$ & $\begin{array}{l}- \\
-\end{array}$ \\
\hline $\begin{array}{l}\text { Simulation model } \\
\text { (a) Historic data ( } 52 \text { yrs) } \\
\text { (i) Policy } 4 \\
\text { (ii) Policy } 5\end{array}$ & $\begin{array}{l}95 \\
94\end{array}$ & $\begin{array}{r}95.43 \\
103.60\end{array}$ & - \\
\hline (b) Generated data (1000 yrs) & & & \\
\hline $\begin{array}{l}\text { Policy } 4 \\
\text { (i) } 20 \text { sequences of } 50 \mathrm{yrs} \\
\text { (ii) } 25 \text { sequences of } 40 \mathrm{yrs} \\
\text { (iii) } 40 \text { sequences of } 25 \mathrm{yrs} \\
\text { (iv) } 50 \text { sequences of } 20 \mathrm{yrs}\end{array}$ & $\begin{array}{l}98 \\
98 \\
98 \\
98\end{array}$ & $\begin{array}{l}- \\
- \\
-\end{array}$ & $\begin{array}{l}102 \cdot 23 \\
102 \cdot 24 \\
102 \cdot 03 \\
101 \cdot 94\end{array}$ \\
\hline $\begin{array}{l}\text { Policy } 5 \\
\text { (i) } 20 \text { sequences of } 50 \mathrm{yrs} \\
\text { (ii) } 25 \text { sequences of } 40 \mathrm{yrs} \\
\text { (iii) } 40 \text { sequences of } 25 \mathrm{yrs} \\
\text { (iv) } 50 \text { sequences of } 20 \mathrm{yrs}\end{array}$ & $\begin{array}{l}97 \\
97 \\
97 \\
96\end{array}$ & $\begin{array}{l}- \\
- \\
-\end{array}$ & $\begin{array}{l}108-25 \\
108 \cdot 24 \\
108 \cdot 12 \\
108 \cdot 04\end{array}$ \\
\hline
\end{tabular}

${ }^{*}$ Except for 3 years -9 th, 10th and 20th years for which the percentages are 45,43 and 54 , respectively.

the length of the sequences used in either policy. The computations of the exceedance probabilities using simulation based on the generated data are given by Mohan (1983). The results presented in the paper are obtained for the specific irrigation demand in table 3.

\section{Summary of results}

Table 8 presents a brief summary of results obtained with optimization and simulation with two of the policies tested. The percentage of the irrigation demand satisfied and the maximum possible hydropower generation as average annual values are given for each of the cases listed. The comparison of the performance using the policies 4 and 5 with the historic performance (for the 11-year period considered) has been made in table 7 and discussed earlier. The results of simulation with generated data in table 8 give an idea of the possible outcome in the long run with the use of the policies 4 and 5 . It is seen that with a marginal tolerance of 2 to $3 \%$ in meeting the specified irrigation demand, there is a significant increase in the hydropower generation with either policy - $44 \%$ increase with policy 4 and $47 \%$ with policy 5 compared with the average actual production in the 11-year period of 1971-72 to 1981-82 during which time the irrigation releases also fell short of the demand by $7 \%$ on the average.

It is to be reiterated here that significant increase in the hydropower generation is obtained with what is considered to be a rather stringent irrigation demand - the 


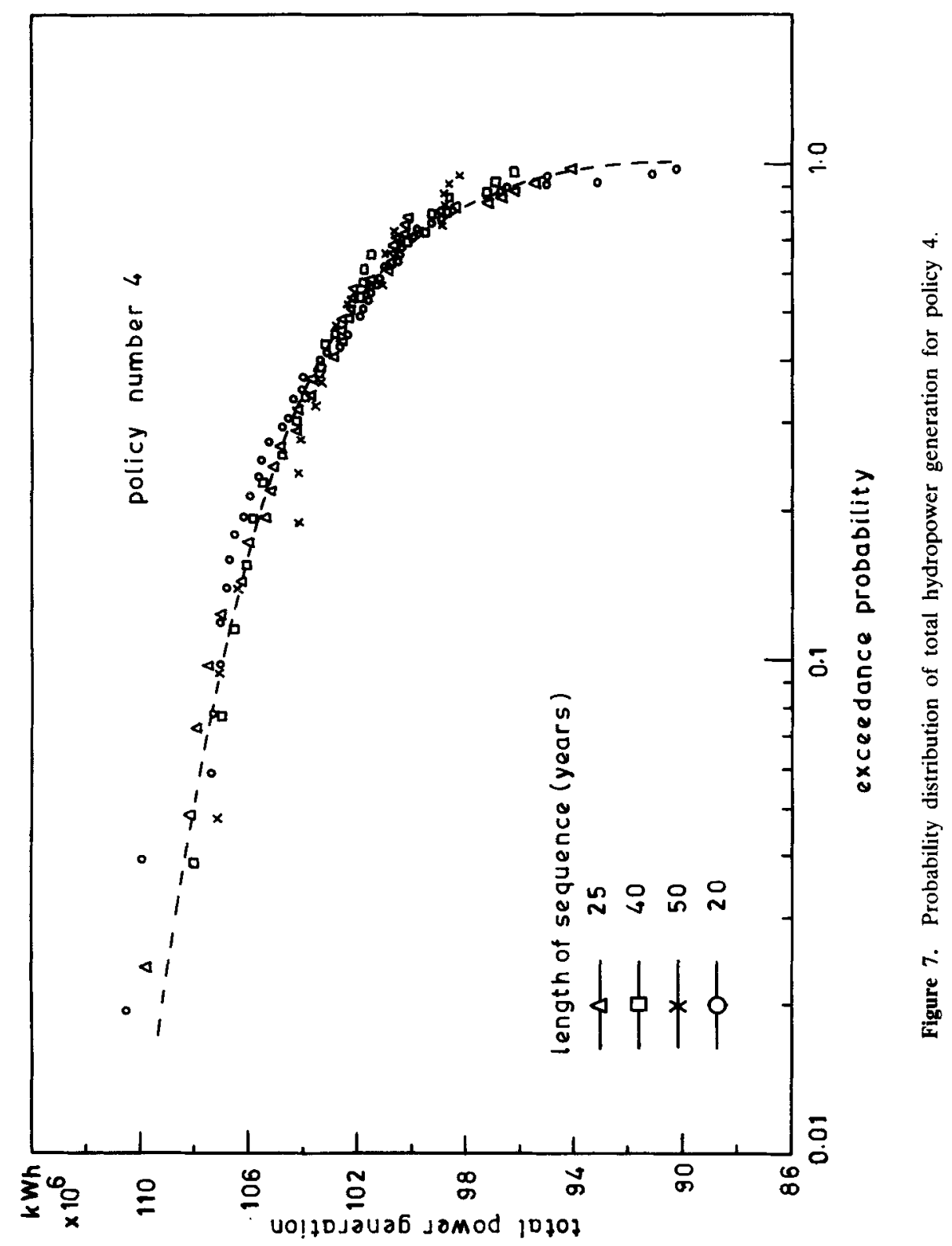




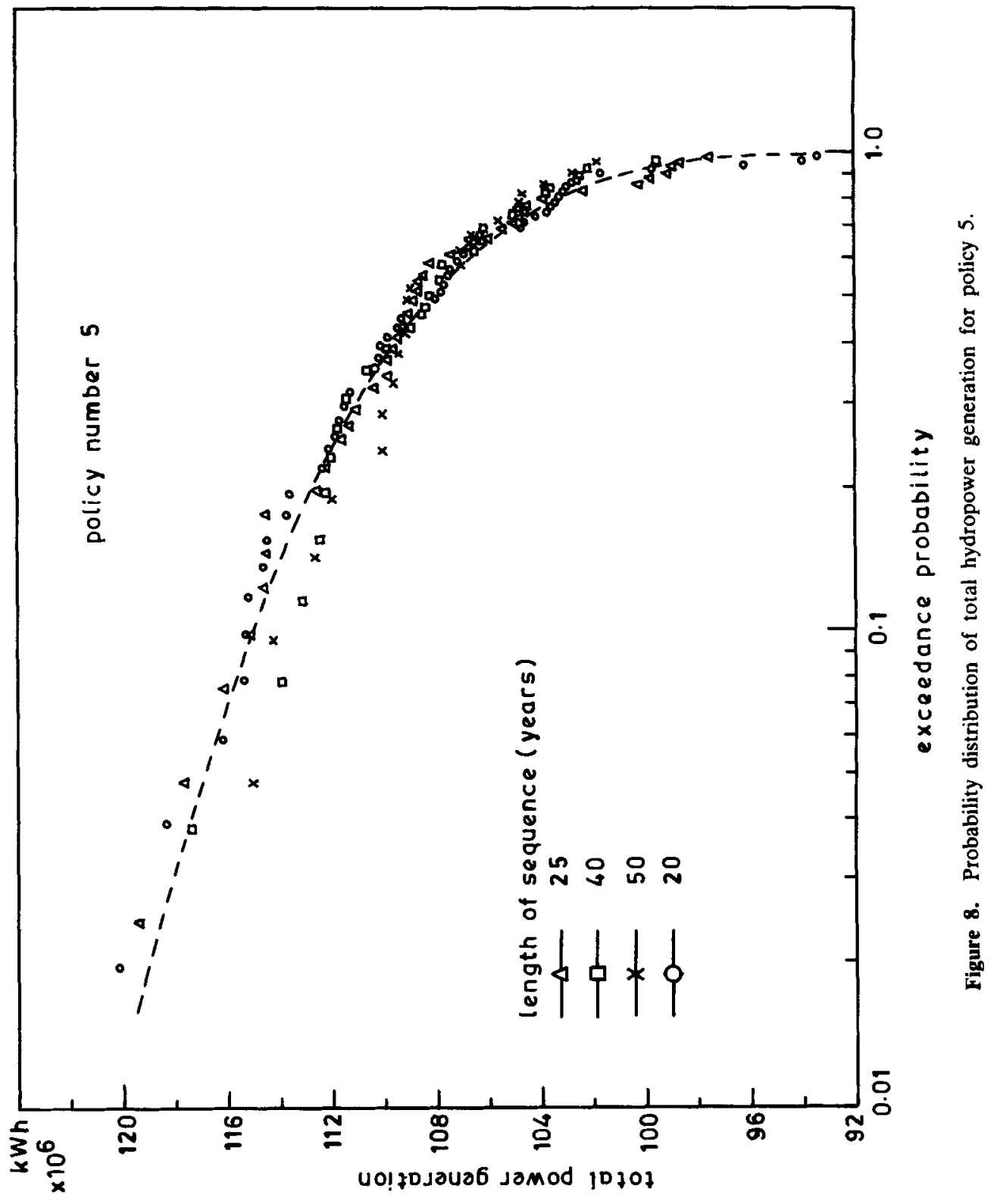


higher of the estimated monthly canal water requirements as per the cropping schedule and of the average actual monthly canal withdrawals.

\section{Conclusion}

The potential for hydropower generation at the Bhadra reservoir project is investigated using both optimization and simulation models. The release policy for the bed turbine operation holds the key for attainment of higher energy production. Operating policies promising substantial increase in the total hydropower production at the project are identified. A comparison of the performance with the identified policies with the actual performance made over a period of 11 years shows a significant increase in the hydropower production than has been possible thus far without sacrificing the irrigation component.

The wholehearted cooperation and the assistance received from the officers of the Water Resources Development Organisation, Government of Karnataka, and the Karnataka Power Corporation, in providing all the necessary data for the present study, are gratefully acknowledged.

\section{List of symbols}

$D M R$ constant monthly downstream release irrespective of release to bed turbine (m cu m)

$D Y R$ constant annual downstream release irrespective of release to bed turbine ( $\mathrm{m} \mathrm{cu} \mathrm{m}$ )

$E B \quad$ annual bed turbine hydropower production $\left(10^{6} \mathrm{kWh}\right)$

$E L$ annual left bank turbine hydropower production $\left(10^{6} \mathrm{kWh}\right)$

$E R$ annual right bank turbine hydropower production $\left(10^{6} \mathrm{kWh}\right)$

$E B W_{t}$ bed turbine hydropower production in month $t$

$E L W_{t}$ left bank turbine hydropower production in month $t$

$E R W_{t}$ right bank turbine hydropower production in month $t$

$H$ reservoir stage $(\mathrm{m})$

$H_{0} \quad$ minimum reservoir stage for bed turbine operation (m)

$H B$ selected reservoir stage at which bed turbine operates at full capacity (m)

$I_{t} \quad$ reservoir inflow in month $t(\mathrm{~m} \mathrm{cu} \mathrm{m})$

$I_{y}$ reservoir inflow in year $y(\mathrm{~m} \mathrm{cu} \mathrm{m})$

$I L W_{t}$ left bank canal irrigation demand in month $t(\mathrm{~m} \mathrm{cu} \mathrm{m})$

$I R W_{t}$ right bank canal irrigation demand in month $t$ (m.cu m)

$K_{0} \quad$ overyear storage capacity (m cu m)

$K_{w} \quad$ within year storage capacity (m cu m)

$L$ annual reservoir evaporation loss ( $\mathrm{m} \mathrm{cu} \mathrm{m}$ )

$L_{t} \quad$ reservoir evaporation loss in month $t(\mathrm{~m} \mathrm{cu} \mathrm{m})$

$O_{t} \quad$ reservoir spill in month $t(\mathrm{~m} \mathrm{cu} \mathrm{m})$

$O_{y} \quad$ reservoir spill in year $y(\mathrm{~m} \mathrm{cu} \mathrm{m})$ 
$Q B \quad$ required monthly bed turbine release for capacity production at reservoir stage $H$ (m cu m)

$Q B^{\prime} \quad$ reduced monthly bed turbine release at reservoir stage $H$ (m cu m)

$R B W_{t}$ release through bed turbine in month $t(\mathrm{~m} \mathrm{cu} \mathrm{m})$

$R L W_{t}$ left bank canal release in month $t(\mathrm{~m} \mathrm{cu} \mathrm{m})$

$R R W_{t}$ right bank canal release in month $t$ (m cu $\left.\mathrm{m}\right)$

$S_{y} \quad$ overyear storage at the beginning of year $y(\mathrm{~m} \mathrm{cu} \mathrm{m})$

$S W_{t} \quad$ within year storage at the beginning of month $t(\mathrm{~m} \mathrm{cu} \mathrm{m})$

$Y$ total annual irrigation demand ( $\mathrm{m} \mathrm{cu} \mathrm{m}$ )

$\alpha_{y} \quad$ ratio of total annual irrigation release to the annual irrigation demand

\section{References}

Beik S E, Yun-Sheng Yu 1984 J. Water Resour. Planning Manage. Div., Am. Soc. Civil. Eng. 110: 1-14 Fiering M B, Jackson B B 1971 Synthetic Streamflows, Water Resources Monograph No. 1, American Geophysical Union, Washington, DC

Fults D M, Hancock L F 1972 J. Hydraul. Div., Am. Soc. Civ. Eng. 98(HY9): 1497-1514

Hall W A, Butcher W S, Esogbue A 1968 Water Resour. Res. 4: 471-477

Loucks D P, Stedinger J R, Haith D A 1981 Water resource systems planning and analysis (Englewood Cliffs, NJ: Prentice Hall)

Mobasheri F, Harboe R C 1970 Water Resour. Res. 6: 22-31

Mohan S 1983 A systems study for the operation of multipurpose Bhadra Reservoir Project, M.E. Dissert., Indian Inst. Sci., Bangalore

Shrestha V S 1976 Optimal operation for multipurpose use of Bhadra Reservoir. M.E. Dissert., Indian Inst. Sci., Bangalore

Thomas H A, Revelle R 1966 Manage. Sci. 12: B296-B311

Water Management Division 1971 A guide for estimating irrigation water requirements, Tech. Series 2, Ministry of Agriculture, Govt. of India, New Delhi 